\title{
Regulation of Calcium Channel Expression in Neonatal Myocytes by Catecholamines
}

\author{
Tiina Maki,§ E. James Gruver, ${ }^{\star}$ Amy J. Davidoff, $\|$ Nicholas Izzo, ${ }^{\star}$ Darlene Toupin, ${ }^{\star}$ Wilson Colucci,, Andrew R. Marks, \\ and James D. Marsh \\ *Cardiovascular Division, Departments of Medicine, Brigham and Women's Hospital and Harvard Medical School, Boston, \\ Massachusetts 02167; ${ }^{\ddagger}$ epartment of Medicine, Mt. Sinai School of Medicine, New York 10029; ${ }^{\S}$ Department of Clinical Chemistry, \\ University of Helsinki, Helsinki, Finland; and ${ }^{\| C a r d i o l o g y ~ D i v i s i o n, ~ H a r p e r ~ H o s p i t a l ~ a n d ~ W a y n e ~ S t a t e ~ U n i v e r s i t y, ~ S c h o o l ~ o f ~ M e d i c i n e, ~}$ \\ Detroit, Michigan 48201
}

\begin{abstract}
Expression of the dihydropyridine (DHP) receptor $\left(\alpha_{1}\right.$ subunit of L-type calcium channel) in heart is regulated by differentiation and innervation and is altered in congestive heart failure. We examined the transmembrane signaling pathways by which norepinephrine regulates DHP receptor expression in cultured neonatal rat ventricular myocytes. Using a 1.3-kb rat cardiac DHP receptor probe, and Northern analysis quantified by laser densitometry, we found that norepinephrine exposure produced a 2.2 -fold increase in DHP receptor mRNA levels at $2 \mathrm{~h}$ followed by a decline to $50 \%$ of control at $4-48 \mathrm{~h}(P<0.02)$. The $\alpha$-adrenergic agonist phenylephrine and a phorbol ester produced a decline in mRNA levels $(8-48 \mathrm{~h})$. The $\beta$-adrenergic agonist isoproterenol and 8-bromo-cAMP produced a transient increase in mRNA levels. After $24 \mathrm{~h}$ of exposure to isoproterenol, ${ }^{3} \mathrm{H}-(+) \mathrm{PN} 200-110$ binding sites increased from $410 \pm 8$ to $539 \pm 39 \mathrm{fmol} / \mathrm{mg}(P<0.05)$. The number of functional calcium channels, estimated by whole-cell voltage clamp experiments, was also increased after $24 \mathrm{~h}$ of exposure to isoproterenol. Peak current density (recordings performed in absence of isoproterenol) increased from $-10.8 \pm 0.8(n=$ $23)$ to $-13.9 \pm 1.0 \mathrm{pA} / \mathrm{pF}(n=27)(P<0.01)$. Other characteristics of the calcium current (voltage for peak current, activation, and inactivation) were unchanged. Exposure for $48 \mathrm{~h}$ to phenylephrine produced a significant decline in peak current density $(P<0.01)$. We conclude that $\beta$-adrenergic transmembrane signaling increases DHP receptor mRNA and number of functional calcium channels and that $\alpha$-adrenergic transmembrane signaling produces a reciprocal effect. Regulation of cardiac calcium channel expression by adrenergic pathways may have physiological and pathophysiological importance. (J. Clin. Invest. 1996. 97:656-663.) Key words: calcium channel • transmembrane signaling • myocyte $\cdot$ transcription
\end{abstract}

Address correspondence to James D. Marsh, M.D., Director, Cardiology Research, Wayne State University School of Medicine, 421 East Canfield Avenue, Detroit, MI 48201. Phone: 313-577-8700; FAX: 313-577-8615.

Received for publication 16 June 1994 and accepted in revised form 31 October 1995.

J. Clin. Invest.

(C) The American Society for Clinical Investigation, Inc. 0021-9738/96/02/0656/08 \$2.00

Volume 97, Number 3, February 1996, 656-663

\section{Introduction}

L-type calcium channels play a pivotal role in normal physiological function of the heart. Contractile performance of the heart is substantially altered when the abundance of functional calcium channels increases or decreases (1-3). In pathophysiological conditions such as congestive heart failure the abundance of calcium channel mRNA and binding sites for calcium channel ligands is significantly depressed (3), possibly contributing to abnormalities in contractile performance in the failing heart. Moreover, relatively little is known about the signaling mechanisms that determine the abundance of calcium channels in cardiac myocytes. Normal calcium channel function in the heart requires the presence of at least the $\alpha_{1}, \alpha_{2}$, and $\beta$ subunits $(4,5)$. Whether subunit protein expression is under important transcriptional control is uncertain; the turnover rate of subunits in the sarcolemma is also unknown. The $\alpha_{1}$ subunit of the calcium channel, which is the dihydropyridine (DHP) ${ }^{1}$ binding site (the DHP receptor), provides the pore structure for $\mathrm{Ca}^{2+}$ ion entry (6-8) and is the best characterized subunit.

We have reported previously that sympathetic innervation in vitro can alter abundance of functional L-type calcium channels (9). Among the potential neuroeffectors released from sympathetic nerve endings, norepinephrine, a combined $\alpha$ - and $\beta$-adrenergic agonist, is a likely candidate for a regulator of calcium channel expression. Sustained exposure to the $\alpha$-adrenergic agonist phenylephrine in vivo has been shown to alter calcium currents in isolated guinea pig ventricular cells (10) and prolonged phenylephrine infusion in rats induces a decrease in DHP receptors in the myocardium (11). Moreover, the $\beta$-adrenergic agonist isoproterenol has been reported to alter DHP receptor expression in cultured chick ventricular cells (1). Circulating norepinephrine and epinephrine is markedly elevated in patients with congestive heart failure (12), a condition in which mRNAs encoding some calcium modulating proteins show depressed expression (3,13). Accordingly, we tested the hypothesis that norepinephrine alters abundance of DHP receptor mRNA, protein, and functional L-type calcium channels in a rat ventricular myocyte model system. We examined the role of adrenergic signaling pathways in regulation of the DHP receptor $\alpha_{1}$ subunit mRNA and its cognate protein.

\section{Methods}

Neonatal cardiac ventricular myocyte cultures. 2-d-old rats were killed by decapitation, hearts were aseptically removed, and ventricles were

1. Abbreviations used in this paper: DHP, dihydropyridine; HP, holding potential; IBMX, isobutyl methylxanthine; $\mathrm{I}_{\mathrm{Ca}}, \mathrm{Ca}^{2+}$ current; $\mathrm{I}_{\mathrm{Na}}$, $\mathrm{Na}^{+}$current; I-V, current-voltage. 
dissected, minced, and exposed to trypsin (Gibco Laboratories, Grand Island, NY) treatment overnight at $4^{\circ} \mathrm{C}$. Subsequently, the cells were dissociated by repetitive collagenase (Worthington Biochemical Corp., Freehold, NJ) treatment at $37^{\circ} \mathrm{C}$, centrifuged at $800 \mathrm{~g}$ $\left(4^{\circ} \mathrm{C}\right)$, and preplated in culture flasks for $75 \mathrm{~min}$ at $37^{\circ} \mathrm{C}$. The flask was gently shaken and nonadherent cells were transferred to another flask for an additional 75 min of preplating. Subsequently, the nonattached cells (myocytes) were counted and plated on 100-mm culture plates at a concentration of $2.1-4.2 \times 10^{6}$ cells $/$ plate $\left(265-530 / \mathrm{mm}^{2}\right)$ in DMEM (Gibco Laboratories) supplemented with $7 \%$ fetal calf serum, streptomycin, and penicillin. Cultures were maintained in a humidified $5 \% \mathrm{CO}_{2}, 95 \% \mathrm{O}_{2}$ atmosphere. After $24 \mathrm{~h}$, the medium was changed to serum-free DMEM containing $10^{-9} \mathrm{M}$ triiodothyronine ( $\mathrm{T}_{3}$; Sigma Immunochemicals, St. Louis, MO), $5 \mathrm{ng} / \mathrm{ml}$ insulin, $5 \mathrm{ng} /$ $\mathrm{ml}$ transferrin, and $5 \mathrm{pg} / \mathrm{ml}$ selenium (ITS premix; Collaborative Research Inc., Bedford, MA). This concentration of $\mathrm{T}_{3}$ in serum-free medium has been shown to be important for maintenance of a stable rate of protein synthesis $(14,15)$ and for phenotypic stability of cultured rat myocytes (16). Serum-free medium helps limit proliferation of nonmyocytes and helps maintain the phenotype of the ventricular myocytes $(14,16)$. After $24 \mathrm{~h}$ of culture in serum-free medium the experiments were initiated. For histochemical staining and for $\mathrm{Ca}^{2+}$ current studies cells were plated on glass coverslips (Fisher Scientific Co., Pittsburgh, PA). For other purposes, cells were grown on 100-mm culture dishes (Falcon Labware, Lincoln Park, NJ). Typically, cells started spontaneous beating after $2 \mathrm{~d}$ in culture. (-)Norepinephrine, (-)isoproterenol- $\mathrm{HCl},(-)$ phenylephrine- $\mathrm{HCl}$, isobutyl methylxanthine (IBMX), DL-propranolol-HCl, and prazosin- $\mathrm{HCl}$ were from Sigma Immunochemicals.

Histochemical staining. To assess the percentage of myocytes in cultures, myocytes were stained for the presence of filamentous actin with bodipy-coupled phallotoxin (Molecular Probes Inc., Eugene, OR); 400 cells were counted from photographs.

Probe for DHP receptor. A 570-bp PCR-generated rat heart DHP receptor $\alpha_{1}$ subunit cDNA that has been described previously (17) was used to screen a rat heart $\gamma \mathrm{gt} 11 \mathrm{cDNA}$ library. A $1.3-\mathrm{kb}$ cDNA (rDHPR-C1), corresponding to nucleotides 2411-3712 of the rabbit heart DHP receptor $\alpha_{1}$ subunit (7), was isolated from this library and used as a probe for Northern and slot blot hybridizations in the present study. rDHPR-C1 encodes the II-S6 region of the rat heart DHP receptor $\alpha_{1}$ subunit and is $92 \%$ identical to the published rabbit sequence. Northern hybridizations using heart DHP receptor $\alpha_{1}$ subunit cDNA probes typically identify three mRNAs in rabbit and mouse, $\sim 8,9.5$, and $22 \mathrm{~kb}(7,18,19)$. In the rabbit all three mRNAs are regulated coordinately during development (18).

Preparation of RNA and Northern analysis. Total RNA was extracted from myocytes on culture plates with guanidium thiocyanatephenol-chloroform by the single step method as described by Chomczynski and Sacchi (20). RNA was quantitated by spectrophotometry at $260 \mathrm{~nm}$; the $260 / 280 \mathrm{~nm}$ ratio was $>1.7$ in all samples.

Total RNA ( 15 or $20 \mu \mathrm{g} / \mathrm{lane}$ ) was run on $1.2 \%$ agarose-formaldehyde gels. Nucleic acids were transferred to nylon membranes (Zeta-Probe; Bio Rad Laboratories, Hercules, CA) either by capillary transfer in $20 \times$ SSC overnight or by vacuum transfer in $10 \times$ SSC for $90 \mathrm{~min}$. After ultraviolet linkage of RNA to filters the blots were hybridized with the 1.3-kb cDNA probe for the rat cardiac DHP receptor labeled with $\left[{ }^{32} \mathrm{P}\right] \mathrm{dCTP}$ by the random primer method (Stratagene, La Jolla, CA). Hybridization was carried out at $42^{\circ} \mathrm{C}$ overnight in $50 \%$ formamide, $1 \mathrm{mM}$ EDTA, $7 \%$ SDS, $0.25 \mathrm{M}$ Na phosphate, 100 $\mathrm{mg} / \mathrm{ml}$ herring sperm DNA, $5 \times$ Denhardt's solution. Blots were washed with $0.5 \times \mathrm{SSC} / 0.1 \% \mathrm{SDS}$ at room temperature for $15 \mathrm{~min}$ followed by $5-20 \mathrm{~min}$ wash in $0.2 \times \mathrm{SSC} / 0.1 \% \mathrm{SDS}$ at $45^{\circ} \mathrm{C}$. Blots were exposed to Kodak XRP or XAR film with two intensifying screens at $-70^{\circ} \mathrm{C}$ for $1-4 \mathrm{~d}$ and developed. Filters were exposed for varying times to ensure that signals were in the linear range for densitometric analysis. For $\alpha$-adrenoceptor studies a full length cDNA probe to the $\alpha_{1 \mathrm{~B}}$ receptor (21) was used. To normalize for possible differences in amount of RNA loaded on gels, filters were subsequently hybridized with a ${ }^{32} \mathrm{P}$-labeled oligonucleotide complementary to $18 \mathrm{~S}$ ribosomal RNA, washed, and autoradiographed (22). Autoradiograms were quantified using laser densitometry (LKB Instruments Inc., Bromma, Sweden) or by digital imaging densitometry (AMBIS, Inc., San Diego, CA) and the DHP receptor band intensities were normalized to that of $18 \mathrm{~S}$ rRNA.

Slot blot analysis. For slot blot analysis, 2, 4, and $8 \mu \mathrm{g}$ total RNA was aliquoted and diluted in $50 \%$ formamide, $7 \%$ formaldehyde, and $1 \times$ SSC. After $15 \mathrm{~min}$ of incubation at $68^{\circ} \mathrm{C}$ the samples were cooled on ice. After adding $2 \mathrm{vol}$ of $20 \times$ SSC, the RNA samples were transferred to a nitrocellulose filter with a vacuum slot-blot apparatus (Bio Rad Laboratories). RNA was then cross-linked to filters by ultraviolet light exposure, probed, washed, autoradiographed, and quantified in a manner identical to that for Northern blots. Regression analysis of densitometric scores of the slot blots was performed; the regression coefficients were typically $>0.98$.

Ligand binding studies. DHP binding studies were carried out as described previously (9). Cells were scraped from culture dishes into ice-cold buffer (50 mM Hepes, $1 \mathrm{mM} \mathrm{MgCl}, 1 \mathrm{mM}$ EDTA, pH 7.4) also containing protease inhibitors $(2 \mu \mathrm{g} / \mathrm{ml}$ leupeptin, $1 \mu \mathrm{g} / \mathrm{ml}$, aprotinin, $0.1 \mathrm{mM}$ benzamidine, $1 \mu \mathrm{M}$ iodoacetamide, $10 \mu \mathrm{g} / \mathrm{ml}$ trypsin inhibitor, and $1 \mu \mathrm{g} / \mathrm{ml}$ pepstatin). Cells were then disrupted with a Polytron homogenizer and debris was pelleted with a $180-g$ centrifugation for $5 \mathrm{~min}$ at $4^{\circ} \mathrm{C}$. The supernatant was collected and centrifuged further at $42,000 \mathrm{~g}$ for $30 \mathrm{~min}$ at $0^{\circ} \mathrm{C}$. The resulting crude membrane pellet was suspended in the same ice-cold buffer, and ${ }^{3} \mathrm{H}-(+) \mathrm{PN} 200-110$ (isradipine) binding (eight concentrations, $100-3,500 \mathrm{pM}$ ) was carried out in the presence or absence of $10^{-6} \mathrm{M}$ unlabeled nitrendipine at $37^{\circ} \mathrm{C}$ for $30 \mathrm{~min}$. Binding was terminated by rapid filtration through GF/B filters (Whatman Inc., Clifton, NJ) using a Brandel cell harvester (Brandel, Inc., Gaithersburg, MD). Bound radioactivity was determined by liquid scintillation spectrometry (Wallac, Gaithersburg, MD). The ligand binding data were analyzed by a modification of LIGAND program with a microVax computer as described previously (23). Nonspecific binding was $<10 \%$ of total binding near the $K_{\mathrm{d}}$. Protein determination was by the method of Lowry.

Electrophysiological measurements. Whole-cell $\mathrm{Na}^{+}$current $\left(\mathrm{I}_{\mathrm{Na}}\right)$ and $\mathrm{Ca}^{2+}$ current $\left(\mathrm{I}_{\mathrm{Ca}}\right)$ were recorded using standard voltage clamp techniques. Experiments were performed using borosilicate glass micropipettes with a filled tip resistance of 3-4 Mohm. Membrane voltages were computer software controlled (pClamp software; Axon Instruments, Inc., Foster City, CA), and whole-cell currents were amplified and then filtered at $5 \mathrm{kHz}$ (Axopatch 1-C amplifier; Axon Instruments, Inc.) and stored on computer for off-line analysis. Whole-cell currents were initially recorded during superfusion with a modified Tyrode's solution containing $(\mathrm{mM})$ : $135 \mathrm{NaCl}, 4 \mathrm{KCl}, 1.8$

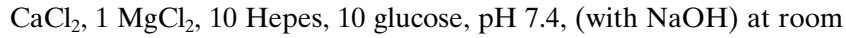
temperature. Control cells and cells cultured with catecholamine-containing medium for $24 \mathrm{~h}$ were washed by superfusing with the modified Tyrode's buffer for at least 15 min to remove catecholamines before the experiment. No catecholamines were present in the buffer during experiments. After establishing whole-cell configuration and adjusting series resistance, current stability was assessed by a doublepulse protocol, in which membrane voltage was stepped from a holding potential of -80 to $-40 \mathrm{mV}$ (for $50 \mathrm{~ms}$ ), and then to $0 \mathrm{mV}$ (for 50 $\mathrm{ms}$ ). These voltages were chosen to selectively activate and monitor $\mathrm{I}_{\mathrm{Na}}$ and $\mathrm{I}_{\mathrm{Ca}}$, respectively. When holding current and ionic currents were stable, an $\mathrm{Na}^{+}$- and $\mathrm{K}^{+}$-free solution was applied through a multibarrel pipette placed within $300 \mu \mathrm{m}$ of the cell, which permitted rapid changes of extracellular solution. Unless otherwise stated, this extracellular solution contained (mM): 135 choline- $\mathrm{Cl}, 1.8 \mathrm{CaCl}_{2}, 1.0$ $\mathrm{MgCl}_{2}, 10$ Hepes, 10 glucose, $\mathrm{pH} 7.4$ (with $\mathrm{CsOH}$ ). In some experiments, $1.8 \mathrm{mM} \mathrm{Ba}^{2+}$ was used as a charge carrier in lieu of $\mathrm{Ca}^{2+}$ $\left(\mathrm{MgCl}_{2}\right.$ was omitted and $100 \mu \mathrm{M}$ EGTA was added) (24). When superfusing with $\mathrm{Na}^{+}$- and $\mathrm{K}^{+}$-free solution the $\mathrm{I}_{\mathrm{Na}}$ was abolished and the $\mathrm{I}_{\mathrm{Ca}}$ remained stable or else increased. Although the mechanisms were not explored, the increase in $\mathrm{I}_{\mathrm{Ca}}$ when external $\mathrm{Na}^{+}$and $\mathrm{K}^{+}$ were removed may be due to the removal of a blocking effect of $\mathrm{Na}^{+}$ 
on $\mathrm{Ca}^{2+}$ conductance $(25,26)$ or perhaps due to better voltage control when holding current decreased in the $\mathrm{K}^{+}$-free solution.

Cells were internally dialyzed with a pipette solution designed to block outward $\mathrm{K}^{+}$currents and to maintain low intracellular $\mathrm{Cl}^{-}$concentration (mM): 120 Cs-aspartate, 10 EGTA, 4 MgATP, 10 Hepes, 10 TEA, pH 7.2 (with $\mathrm{CsOH}$ ). $\mathrm{I}_{\mathrm{Ca}}$ in these cells were highly prone to rundown. More than $60 \%$ of the cells exhibited significant rundown within the first few minutes of recording and were excluded from this study. A variety of internal and external solutions were evaluated for attenuating rundown. There were no apparent differences in the rate or extent of rundown when either $10 \mu \mathrm{M}$ cAMP was added to the internal solution or an ATP regenerating internal solution was used (26). $\mathrm{Cs}^{+}$in the internal solution was not sufficient to block all outward current (especially at positive potentials above $+20 \mathrm{mv}$ ); it was necessary to include TEA in the pipette solution. In a subset of myocytes, $\mathrm{I}_{\mathrm{Ca}}$ was recorded during superfusion with choline-Cl-containing buffer, then switched to equimolar TEA-Cl. There was no difference in $\mathrm{I}_{\mathrm{Ca}}$ when recorded in either buffer. These experiments were conducted to determine whether choline exhibited any cholinergic effects on $\mathrm{I}_{\mathrm{Ca}}$ in this system.

Inward currents were activated by altering the membrane voltage, from a holding potential (HP) of $-80 \mathrm{mV}$, to $+40 \mathrm{mV}$ in $10-\mathrm{mV}$ steps with an interpulse interval of $10 \mathrm{~s}$. It was determined that $\mathrm{Ca}^{2+}$ was the predominant charge carrier through the L-type $\mathrm{Ca}^{2+}$ channel because of its dependence on extracellular $\mathrm{Ca}^{2+}$, sensitivity to both the DHP agonist Bay K $8644(1 \mu \mathrm{M})$ and $\mathrm{Cd}^{2+}(100 \mu \mathrm{M})$, and insensitivity to TTX $(15 \mu \mathrm{M})$. To ascertain whether these cells possessed T-type currents, current-voltage (I-V) relationships were also recorded in some cells from an HP of $-50 \mathrm{mV}$, then the I-V curves were subtracted from currents measured from an $\mathrm{HP}$ of $-80 \mathrm{mV}$ (27). No evidence for T-type currents was found in the cells that were studied in detail (data not shown). Measurements for leak current subtraction were routinely recorded with a small hyperpolarizing step $(-10 \mathrm{mV}$ from HP) after each voltage step protocol. Leak currents were linear up to $+40 \mathrm{mV}$ when assessed in the presence of $100 \mu \mathrm{M}$ extracellular $\mathrm{Cd}^{2+}$. Cell capacitance was estimated by integrating the capacity transient and dividing by the voltage step $(-80$ to $-85 \mathrm{mV})$, and used as an index to normalize $\mathrm{I}_{\mathrm{Ca}}$ for cell size. Steady state inactivation was assessed with a 500-ms prepulse of various voltages (range -100 to $+40 \mathrm{mV}$ ), a 5 -ms interpulse to $-80 \mathrm{mV}$, and a 15 -ms test pulse to the voltage that elicited peak current (usually $+10 \mathrm{mV}$ ). The voltage at which $50 \%$ of the maximal current was still available $\left(V_{0.5}\right)$ and the slope of the linear portion of the inactivation curve $(k)$ were estimated using a Boltzmann equation. Analysis was performed on data points within the linear portion of the curves for each cell.

Whole-cell currents were always recorded from both catecholamine-treated cells and control cells on any given day. Each experimental group from the $\beta$-adrenergic studies represented data collected from four to six separate cell cultures. The following variables were separately analyzed with a parametric $t$ test: peak current density, cell capacitance, $V_{0.5}$, and $k$.

Statistical analysis. Data were analyzed by the Wilcoxon sum rank test or Kruskal-Wallis test for multiple comparisons.

\section{Results}

Regulation of DHP receptor $m R N A$ by norepinephrine. Cells were cultured for $48 \mathrm{~h}(24 \mathrm{~h}$ in serum-containing medium followed by $24 \mathrm{~h}$ in serum-free medium) before initiation of experiments. The myocytes were morphologically stable and changed little over the subsequent $72 \mathrm{~h}$. Percent myocytes in cultures determined histochemically was $>93 \%$ in all preparations and remained stable. After $24 \mathrm{~h}$ in serum-free medium, experiments commenced. Cells were exposed to catecholamines and $0.1 \mathrm{mM}$ ascorbate (to prevent catecholamine oxidation) for $2-48 \mathrm{~h}$. Medium was changed every $24 \mathrm{~h}$.

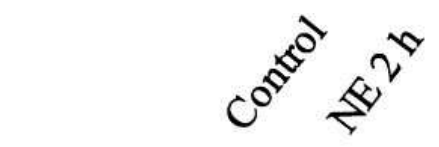

Figure 1. Northern blot analysis of total RNA from rat ventricular myocytes treated with $10^{-8} \mathrm{M}$ norepinephrine (NE)

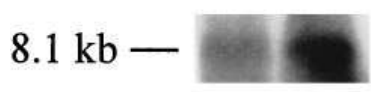

for $2 \mathrm{~h}$. Cells were maintained in serum-free medium for $24 \mathrm{~h}$ before and during NE exposure. Control, control cells; $N E$

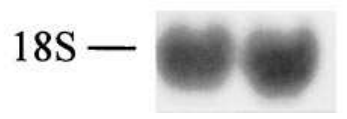

$2 h$, cells exposed to norepinephrine $\left(10^{-8} \mathrm{M}\right)$ for $2 \mathrm{~h}$. DHP receptor 8.1-kb transcript is indicated. $18 \mathrm{~S}$ shows normalization for possible differences in loading of samples using a specific $18 \mathrm{~S}$ rRNA oligonucleotide probe. A marked increase in message for the DHP receptor produced by $2 \mathrm{~h}$ of norepinephrine exposure is evident. This typical experiment was replicated five times with similar results.

Fig. 1 demonstrates a representative Northern blot of total rat cardiomyocyte RNA probed with the cDNA probe for the DHP receptor (rDHPR-C1). In rat heart total RNA, rDHPR-C1 recognized one major band migrating at $\sim 8.1 \mathrm{~kb}$ (Fig. 1 ); two much fainter bands at $\sim 9.5$ and $22 \mathrm{~kb}$ were the only other bands seen. Identical results were obtained by quantifying $\alpha_{1}$ subunit mRNA levels using Northern hybridizations in which the 8.1-kb band was used for quantification and slot blot analyses in which the signal represents hybridization to all three mRNAs. Concentration-response experiments demonstrated that $10^{-8} \mathrm{M}$ norepinephrine produced the maximum change in mRNA levels.

To determine whether in this experimental system norepinephrine could regulate its own signal transduction pathway by altering expression of message for the $\alpha_{1 \mathrm{~B}}$-adrenergic receptor, RNA from norepinephrine-exposed cells was subjected to Northern analysis and hybridized with a cDNA probe for the $\alpha_{1}$-adrenergic receptor $(21,28)$. Over the same time course in which regulation of DHP mRNA abundance occurs, $10^{-6} \mathrm{M}$ norepinephrine decreased mRNA levels for the $\alpha_{1}$-adrenergic receptor approximately two- to threefold. This downregulation of $\alpha_{1 \mathrm{~B}}$ receptor mRNA by norepinephrine is mediated by the $\alpha$-adrenergic receptor because it is blocked by prazosin but not by propranolol (data not shown).

The time course of regulation of DHP receptor mRNA by norepinephrine was examined. Fig. 2 demonstrates that norepinephrine exposure produces, on average, a 2.2-fold increase $(P<0.02)$ in message level for the DHP receptor at $2 \mathrm{~h}$, followed by a decline at 4-48 h; mRNA levels declined significantly to $\sim 50 \%$ of the level observed for cells not exposed to norepinephrine $(P<0.02)$. Control experiments demonstrated no significant change in mRNA level for the DHP receptor for cells grown in serum-free medium for up to $72 \mathrm{~h}$ but not exposed to norepinephrine.

Effects of selective adrenergic agonists on DHP receptor message abundance. To examine the specific $\alpha$-adrenergic component of regulation of DHP receptor message by norepinephrine, myocytes were exposed to phenylephrine for 2-24 h. Phenylephrine reduced the DHP receptor message level to $\sim 30 \%$ of the level in simultaneously studied control cells after 8 and $24 \mathrm{~h}$ (Fig. 3). Phenylephrine did not produce an increase in message level at any time point examined. To circumvent potential problems with $\alpha$-adrenergic receptor regulation by agonist and directly stimulate the protein kinase $C$ signaling path- 


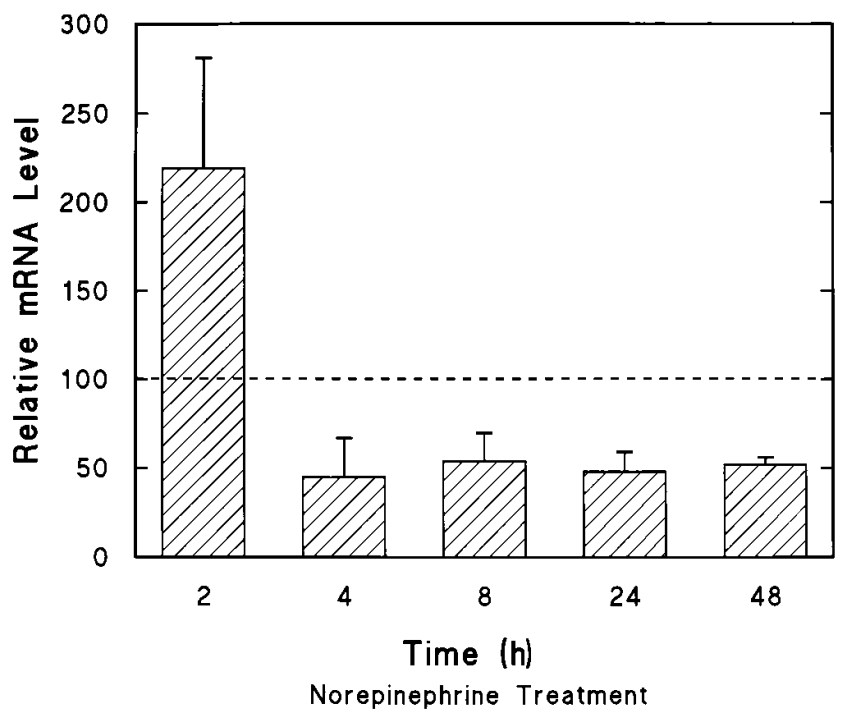

Figure 2. Time course of regulation of DHP receptor mRNA abundance by norepinephrine. Cells in serum-free medium were exposed to norepinephrine for indicated times. mRNA levels of control cells analyzed at each time point in parallel are indicated by the dashed line. Northern and slot blot experiments were analyzed and compared with values from control cells from the same culture at identical time points. mRNA levels relative to that for control cells are shown. At 2, 8, and $24 \mathrm{~h}$, mRNA levels of norepinephrine-exposed cells differed significantly from those of control cells $(P<0.05, n=$ 5-13). Statistical tests were not applied to 4- and 48-h data because of small sample size $(n=2-3)$. A biphasic change in DHP receptor mRNA level is evident.

way, myocytes were treated with the phorbol ester, phorbol 12-myristate 13 -acetate (PMA, $10^{-7} \mathrm{M}$ ) for $24 \mathrm{~h}$. mRNA level for the DHP receptor in treated cells was reduced to $67 \pm 5 \%$ $(P<0.05)$ of that for control cells analyzed in parallel (Fig. 3$)$.

DHP receptor regulation by $\beta$-adrenergic receptor-dependent signaling was then examined. The $\beta$-adrenergic agonist isoproterenol $\left(10^{-8} \mathrm{M}\right)$ induced an approximate doubling in the relative DHP receptor message level at $2 \mathrm{~h}$ when compared with simultaneously studied control cells (Fig. 4). After $24 \mathrm{~h}$ of exposure to isoproterenol, an increase in message level was no longer evident. Higher concentrations of isoproterenol produced less effects, probably due to $\beta$-adrenergic receptor regulation (29). To circumvent the confounding influence of agonist-induced regulation of $\beta$-adrenergic receptors, we used the membrane-permeable cyclic adenosine monophosphate analogue, 8-bromo-cAMP combined with IBMX, a phosphodiesterase inhibitor, to elevated intracellular [cAMP]. This induced a doubling in DHP receptor mRNA levels at $2 \mathrm{~h}$ when compared with control (Fig. 4). Northern and slot blot analysis was used to analyze the detailed time course of DHP receptor message level regulation by catecholamine. The mean data are shown in Table I. Catecholamines with $\beta$-adrenergic agonist properties produced an increase in DHP receptor mRNA levels at $2 \mathrm{~h}$; both $\alpha$ - and $\beta$-adrenergic agonists produced a decline in mRNA levels at times $\geq 8 \mathrm{~h}$.

DHP receptor protein abundance. To determine whether the increase in DHP receptor mRNA produced by a $\beta$-adrenergic agonist results in a subsequent increase in DHP receptor protein, we studied abundance of this protein by ligand bind-

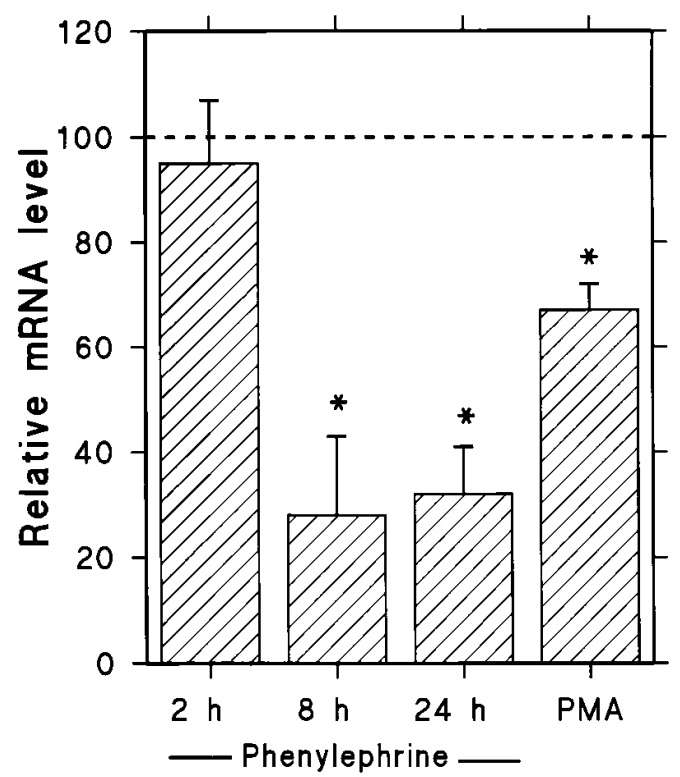

Figure 3. $\alpha$-Adrenergic agonist effect on mRNA levels. Cells were exposed to the $\alpha$-adrenergic agonist phenylephrine $\left(10^{-5} \mathrm{M}\right)$ in the presence of propranolol $\left(10^{-6} \mathrm{M}\right)$ for indicated times. DHP receptor mRNA levels were normalized by $18 \mathrm{~S}$ ribosomal RNA levels and compared with levels in simultaneously analyzed control cells (dashed line). Mean \pm SEM is shown. At 8 and $24 \mathrm{~h}$, DHP receptor mRNA levels were reduced ( $P<0.02, n=3-6$ cultures) for each point. 24-h exposure to the phorbol ester, PMA $\left(10^{-7} \mathrm{M}\right)$, also significantly decreased DHP receptor mRNA levels $(n=5$ cultures, $P<$ $0.05)$.

ing protocols. Cells were exposed to isoproterenol $\left(10^{-8} \mathrm{M}\right)$ for $24 \mathrm{~h}$; prazosin $\left(10^{-6} \mathrm{M}\right)$ was also present in all culture dishes to exclude any $\alpha$-adrenergic effect. Fig. 5 demonstrates typical Scatchard plots of binding data from one representative experiment. On average, isoproterenol-exposed cells had a significantly higher concentration of DHP binding sites $(539 \pm 34$ $\mathrm{fmol} / \mathrm{mg}$ protein) when compared with control cells $(410 \pm 8$ $\mathrm{fmol} / \mathrm{mg}$ protein, $P<0.05$, three experiments for each condition). The affinity of the receptor for the ligand was unchanged $\left(K_{\mathrm{d}}, 200 \pm 34 \mathrm{pM}\right.$ control, $179 \pm 14 \mathrm{pM}$ isoproterenol treatment).

Whole-cell $I_{C a}$. Cultured rat ventricular myocytes express L-type calcium channels; Fig. 6 shows a recording from a typical control cell, demonstrating a current characteristic of $\mathrm{I}_{\mathrm{Ca}}$. It was of interest to determine whether the increase in mRNA for the $\alpha_{1}$ subunit and DHP receptor protein was accompanied by increase of functional $\mathrm{Ca}^{2+}$ channels. Functional calcium channels require assembly of $\alpha_{1}, \alpha_{2}$, and $\beta$ subunits in the sarcolemma. $\mathrm{Ca}^{2+}$ current densities $\left(\mathrm{I}_{\mathrm{Ca}}\right.$ normalized to cell capacitance) were measured in myocytes treated with either $10^{-8} \mathrm{M}$ norepinephrine or $10^{-8} \mathrm{M}$ isoproterenol for $24 \mathrm{~h}$. Both norepinephrine and isoproterenol treatment for $24 \mathrm{~h}$ substantially increased $\mathrm{I}_{\mathrm{Ca}}$, which was recorded in buffer devoid of catecholamines (Fig. 7). For norepinephrine treatment, peak current increased from $-11.5 \pm 0.8$ to $-14.9 \pm 1.9 \mathrm{pA} / \mathrm{pF}(P<0.01)$; for growth of cells in isoproterenol, peak current increased from $-10.8 \pm 0.8$ to $-13.9 \pm 1.0 \mathrm{pA} / \mathrm{pF}(P<0.01)$. Cells were washed in control buffer extensively before the experiment so it is unlikely that the augmented current observed with both $\mathrm{Ca}^{2+}$ and $\mathrm{Ba}^{2+}$ as charge carriers could be due to acute catecholamine 


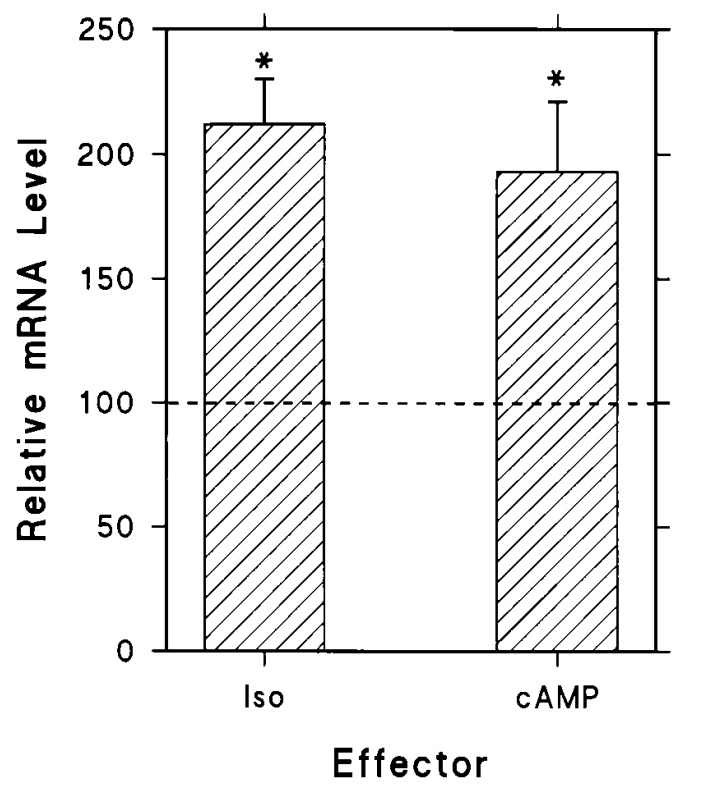

Figure 4. $\beta$-Adrenergic agonist effect on mRNA levels. Northern blot analysis of $10^{-8} \mathrm{M}$ isoproterenol (Iso) and $1 \mathrm{mM}$ 8-bromo-cAMP $(c A M P)$ effects on DHP receptor message after $2 \mathrm{~h}$ of exposure was performed. The experiments were conducted in the presence of $10^{-6} \mathrm{M}$ prazosin. IBMX $\left(10^{-4} \mathrm{M}\right)$ was present during cAMP incubation. This experiment was replicated two to three times with each condition. Abundance of DHP receptor mRNA was normalized by $18 \mathrm{~S}$ RNA levels. On the ordinate, the relative amount of DHP receptor mRNA is shown compared with that present in control cells $(100 \%$, dashed line $)$ analyzed simultaneously. Iso and cAMP increased DHP receptor message levels significantly $(P<0.05)$.

effects on calcium channels. Superfusion with $\mathrm{Ba}^{2+}$ in place of $\mathrm{Ca}^{2+}$ as the charge carrier resulted in an expected increase in peak current amplitude and a reduced rate of current decay (Fig. 6, $C$ and $D$ ). However, it was also observed that peak current was elicited at more negative step potentials (generally $-10 \mathrm{mV}$ ) when compared with $\mathrm{I}_{\mathrm{Ca}}$ (Fig. 7, $A$ and $B$ ). This leftward shift in the I-V curve with $\mathrm{Ba}^{2+}$ was similar to that reported for vascular smooth muscle cells (24) and embryonic ventricular myocytes (27), but differs from those in adult ventricular myocytes where the $\mathrm{I}-\mathrm{V}$ for $\mathrm{Ba}^{2+}$ usually shifts to the right. The biophysical aspects of the I-V shift were not further explored. The increase in whole-cell $\mathrm{I}_{\mathrm{Ca}}$ in cells cultured with catecholamines cannot be attributed to changes in steady state

Table I. Time Course of Modulation of DHP Receptor mRNA Abundance by Catecholamines

\begin{tabular}{lrrccr}
\hline & \multicolumn{5}{c}{ Time (h) } \\
\cline { 2 - 6 } \multicolumn{1}{c}{ Catecholamine } & \multicolumn{1}{c}{2} & \multicolumn{1}{c}{4} & 8 & 24 & 48 \\
\hline Isoproterenol & 212 & 90 & 50 & 54 & ND \\
Norepinephrine & 220 & 51 & 60 & 55 & 56 \\
Phenylephrine & 96 & 102 & 28 & 31 & ND
\end{tabular}

Amount of DHP receptor mRNA from cells exposed to catecholamine for indicated period of time relative to mRNA from simultaneously cultured control cells not exposed to catecholamine. $n=2-6$ for each point. No change $=100 ; N D$, not done.

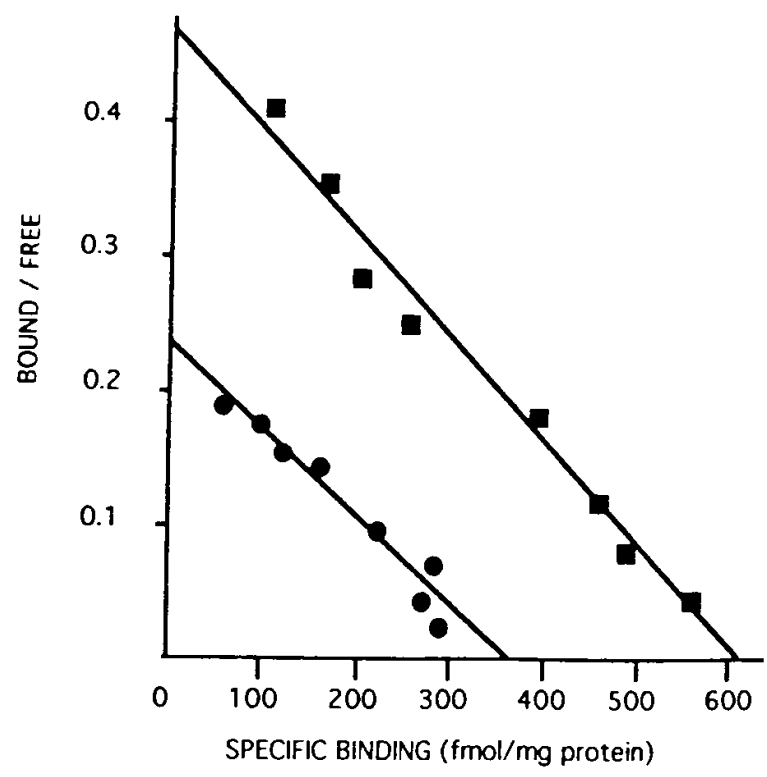

Figure 5. Scatchard analyses of ${ }^{3} \mathrm{H}-(+) \mathrm{PN} 200-110$ binding to crude sarcolemmal membranes. Cells were treated with prazosin $\left(10^{-6} \mathrm{M}\right)$ only (circles) or prazosin with isoproterenol $\left(10^{-8} \mathrm{M}\right.$, squares $)$ for $24 \mathrm{~h}$ under serum-free conditions. This representative experiment was replicated three times.

inactivation kinetics. Fig. $7 \mathrm{D}$ illustrates that a 500 -ms prepulse is sufficient to completely inactivate $\mathrm{I}_{\mathrm{Ca}}$ when $\mathrm{Ca}^{2+}$ is the charge carrier, and that the inactivation curves are the same for myocytes cultured in either control (with prazosin) or isoproterenol (with prazosin) containing serum-free medium. (Similar results were obtained for cells cultured with and without norepinephrine, data not shown.)

Since mRNA for the $\mathrm{Ca}^{2+}$ channel $\alpha_{1}$ subunit was increased by catecholamines within $2 \mathrm{~h}$ of exposure, $\mathrm{I}_{\mathrm{Ca}}$ was evaluated in cells exposed to either norepinephrine or isoproterenol for 6-12 h. Whole-cell $\mathrm{I}_{\mathrm{Ca}}$ were not significantly different at 6-12 h after catecholamine exposure: peak $\mathrm{I}_{\mathrm{Ca}}$ for controls $=7.9 \pm 1.3$ $\mathrm{pA} / \mathrm{pF}(n=17)$ and for catecholamine-exposed cells: $9.5 \pm 1.4$ $\mathrm{pA} / \mathrm{pF}(n=26)$. However, by $24 \mathrm{~h}$ of exposure the increase in $\mathrm{I}_{\mathrm{Ca}}$ was significant. Taken together, these data are consistent with the postulate that there are more functional calcium channels per cell after $24 \mathrm{~h}$ of incubation with a $\beta$-adrenergic agonist because there is more whole-cell $\mathrm{I}_{\mathrm{Ca}}$ and that this current exhibits typical L-type calcium channel characteristics. Of note, mean cell capacitance was not different between the appropriate control cells and cells exposed for $24 \mathrm{~h}$ to either norepinephrine or isoproterenol (average cell capacitance for all groups $19.2 \pm 1.2 \mathrm{pF}, n=86)$. Therefore, changes in cell size or membrane surface area cannot account for an increase in whole-cell $\mathrm{I}_{\mathrm{Ca}}$.

Treatment of myocytes with a $\beta$-adrenergic agonist increased mRNA levels for the DHP receptor and subsequently increased $\mathrm{I}_{\mathrm{Ca}}$; treatment with an $\alpha$-adrenergic agonist decreased mRNA levels for the DHP receptor. Therefore, we determined the effect of an $\alpha$-adrenergic agonist on $\mathrm{I}_{\mathrm{Ca}}$. Cells were exposed to $10^{-5} \mathrm{M}$ phenylephrine plus $10^{-6} \mathrm{M}$ propranolol for $48 \mathrm{~h}$. Treatment with this $\alpha$-adrenergic agonist reduced peak $\mathrm{I}_{\mathrm{Ca}}$ from $-24.9 \pm 2.6 \mathrm{pA} / \mathrm{pF}$ for control cells to $-13.7 \pm 1.2 \mathrm{pA} / \mathrm{pF}$ for treated cells $(P<0.005 ; n=18$ cells for each group). Control cells were exposed to the same concen- 
A

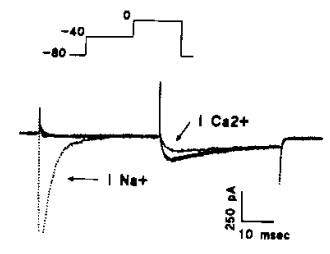

C
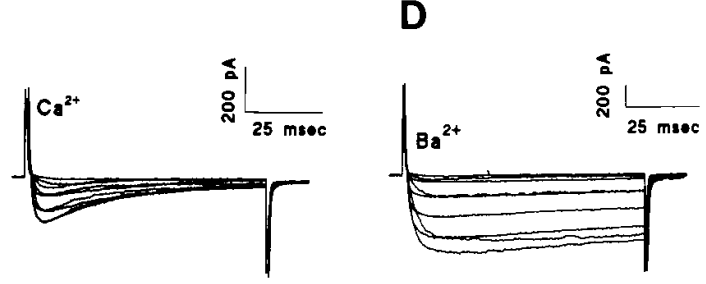

Figure 6. L-type $\mathrm{I}_{\mathrm{Ca}}$ in cultured neonatal rat ventricular myocytes. (A) Recording $\mathrm{I}_{\mathrm{Na}}$ and $\mathrm{I}_{\mathrm{Ca}}$ during voltage clamp of a typical cell from $\mathrm{HP}=-80 \mathrm{mV}$ and stepping to $-40 \mathrm{mV}$ (for $50 \mathrm{~ms}$ ) then to $0 \mathrm{mV}$ (for $50 \mathrm{~ms}) . \mathrm{I}_{\mathrm{Na}}$ is present while superfusing with normal buffer containing $\mathrm{Na}^{+}$and $\mathrm{K}^{+}$(indicated by $\mathrm{I}_{\mathrm{Na}}$ ), but $\mathrm{I}_{\mathrm{Na}}$ is abolished after switching the superfusate to a $\mathrm{Na}^{+}$- and $\mathrm{K}^{+}$-free buffer. When $\mathrm{I}_{\mathrm{Na}}$ is abolished, $\mathrm{I}_{\mathrm{Ca}}$ often becomes larger (see Methods). (B) This $\mathrm{I}_{\mathrm{Ca}}$ is augmented by BAYK8644 $(1 \mu \mathrm{M})$ and can subsequently be washed out $(\mathrm{HP}=-80$ $\mathrm{mV}$ stepped to $+10 \mathrm{mV}$ ). The $\mathrm{I}_{\mathrm{Ca}}$ generally exhibits some rundown especially after a voltage step protocol and after washout of DHPs. $(C$ and $D) \mathrm{Ca}^{2+}$ conductance and $\mathrm{Ba}^{2+}$ conductance evoked from an $\mathrm{HP}$ of $-80 \mathrm{mV}$ and stepped to depolarizing potentials in $10-\mathrm{mV}$ increments (current traces were not leak subtracted). Traces in $C$ and $D$ were recorded from the same cell with a capacitance of $21.7 \mathrm{pF}$.

tration of propranolol as experimental myocytes. There was no change in cell capacitance after treatment with phenylephrine.

\section{Discussion}

There are four principal novel findings of this study of ion channel regulation in heart.

First, norepinephrine regulated DHP receptor mRNA abundance. The time course of DHP receptor mRNA level regulation was biphasic, with an approximately twofold increase at $2 \mathrm{~h}$, followed by a decline to $\sim 50 \%$ of the level observed in control cells between 4 and $48 \mathrm{~h}$. Maximal alteration in mRNA levels occurred with an intermediate concentration of catecholamines. The observation that high concentrations of catecholamines do not produce a maximal modulating effect is not entirely surprising. $\beta$-Adrenergic receptors are rapidly uncoupled from their effector system by high concentrations of agonist, $\alpha$-adrenergic receptors are rapidly uncoupled by a protein kinase $\mathrm{C}$-dependent process, and message is regulated by a receptor-dependent process as well (28-30).

The second finding of this study is that both the $\alpha$-adrenergic and $\beta$-adrenergic signaling pathways could regulate DHP receptor mRNA abundance, but in a reciprocal manner. Signaling via the $\alpha$-adrenergic pathway produced a decrease in message level over a relatively slow time course, whereas $\beta$-adrenergic transmembrane signaling produced a transient,
A

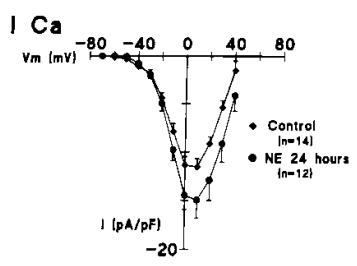

B

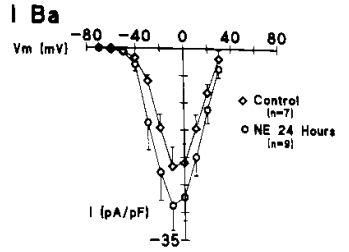

C
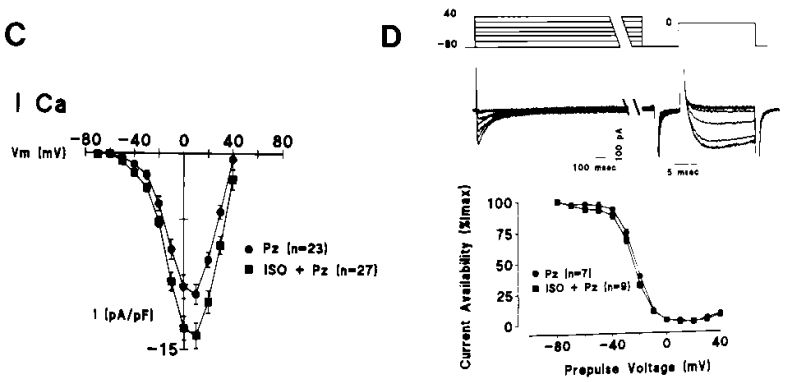

Figure 7. I-V relationship of L-type $\mathrm{Ca}^{2+}$ channel recorded from neonatal ventricular myocytes cultured with adrenergic agonists for $\sim 24 \mathrm{~h}$. All currents were recorded from an $\mathrm{HP}$ of $-80 \mathrm{mV}$ in $\mathrm{Na}^{+}-$ and $\mathrm{K}^{+}$-free buffer that did not contain any agonist. $(A) \mathrm{I}-\mathrm{V}$ from cells cultured with norepinephrine (NE, filled circles) $\left(\mathrm{NE} 10^{-8} \mathrm{M}\right.$; cell capacitances $22.0 \pm 1.9 \mathrm{pF}$ ) or without (filled diamonds) NE (control; cell capacitances $20.9 \pm 1.0 \mathrm{pF}$ ) and in the presence of $1.8 \mathrm{mM}$ $\left[\mathrm{Ca}^{2+}\right]_{0}$ as the charge carrier. (B) I-V from cells cultured with (filled circles) NE $\left(10^{-8} \mathrm{M}\right.$; cell capacitances $\left.19.4 \pm 1.2 \mathrm{pF}\right)$ or without (filled diamonds) NE (control; cell capacitances $17.6 \pm 1.1 \mathrm{pF}$ ) and in the presence of $1.8 \mathrm{mM}\left[\mathrm{Ba}^{2+}\right]_{0}$ as the charge carrier. Currents in $A$ and $B$ were recorded from different cells but peak $\mathrm{Ba}^{2+}$ conductances always occurred at more negative potentials than did peak $\mathrm{Ca}^{2+}$ conductances. $(C) \mathrm{I}-\mathrm{V}$ from control cells (filled circles, cell capacitances $17.1 \pm 0.8 \mathrm{pF}$ ) or (filled squares) cells treated with isoproterenol $\left(I S O=10^{-8} \mathrm{M}\right.$ : cell capacitances $\left.16.7 \pm 0.9 \mathrm{pF}\right)$ and in the presence of $1.8 \mathrm{mM}\left[\mathrm{Ca}^{2+}\right]_{0}$ as the charge carrier. Prazosin $(P z)$ was present during isoproterenol exposure. $(D)$ Steady state inactivation of $\mathrm{I}_{\mathrm{Ca}}$ in control cells (filled circles) or isoproterenol-treated cells (filled squares). The inset illustrates currents recorded during a 500-ms prepulse (from $-80 \mathrm{mV}$ ) to depolarizing potentials, followed by currents recorded during 15-ms test pulses that elicited peak $\mathrm{I}_{\mathrm{Ca}}$ (generally $+10 \mathrm{mV}$ ). Voltage protocol is also shown above the current traces. Boltzmann fit of the linear portion of inactivation curves were not different between each group (the combined $V_{0.5}=26 \pm 1 \mathrm{mV}$ and $k=7.260 .4)$. All values are presented as a mean \pm SE, the numbers of cells $(n)$ are presented in each figure and were recorded from cells isolated from multiple cultures. Peak current densities were significantly greater in catecholamine-exposed cells than in the respective control cells $(P<0.01$ in $A-C)$.

significant increase in mRNA level after $2 \mathrm{~h}$ of exposure. The $\beta$-adrenergic agonist effect of increasing mRNA levels could be reproduced by a cyclic AMP analogue, implicating protein kinase $\mathrm{A}$ in the regulatory pathway. The $\alpha$-adrenergic effect (decrease in mRNA level for the DHP receptor) could be produced by stimulating the protein kinase $\mathrm{C}$ pathway with PMA.

The third finding of these experiments was that after the increase in DHP receptor message, there was an increase in DHP receptor protein as assessed by ligand binding studies. The dissociation constant for antagonist binding to the DHP receptor was unchanged, suggesting that there were no important structural changes in the binding site. 
The fourth finding of this study was that subsequent to a $\beta$-adrenergic agonist-induced increase in abundance of DHP receptor mRNA, there was an increase in whole-cell $\mathrm{I}_{\mathrm{Ca}}$ (recorded in the absence of $\beta$-adrenergic agonists). The increase in whole-cell $\mathrm{I}_{\mathrm{Ca}}$ was not fully realized until $24 \mathrm{~h}$ in culture. $\mathrm{I}_{\mathrm{Ca}}$ density $(\mathrm{pA} / \mathrm{pF})$ was increased while there was no change in either cell capacitance, activation, or steady state inactivation characteristics. Therefore, it is not likely that the increase in whole-cell current could be attributed to cell hypertrophy or changes in voltage dependence of the whole-cell current, but rather to an increase in the number of functional sarcolemmal calcium channels. Moreover, subsequent to $\alpha$-adrenergic agonist-induced decrease in message level, there was a decrease in $\mathrm{I}_{\mathrm{Ca}}$.

Although a change in probability of channel opening from a stable population of channels as an explanation for an increase in $\mathrm{I}_{\mathrm{Ca}}$ density cannot be excluded with the present data, the alternative explanation, that there is a change in number of channels, we view as more likely. Subsequent to an increase in mRNA for the DHP receptor, and simultaneous with more DHP receptors being present in the cell membranes, $\mathrm{I}_{\mathrm{Ca}}$ density increased. Subsequent to a decline in mRNA for the DHP receptor produced by phenylephrine (Table I and Fig. 3), $\mathrm{I}_{\mathrm{Ca}}$ density decreased. Taken together, these data suggest that sarcolemmal $\mathrm{I}_{\mathrm{Ca}}$ is regulated at least in part by the abundance of the $\alpha_{1}$ subunit of the calcium channel, which in turn is modulated by adrenergic receptor stimulation. This is a novel finding for calcium channels in cardiac myocytes. The time course of increase in message $2 \mathrm{~h}$ after $\beta$-adrenergic agonist exposure and increase in $\mathrm{I}_{\mathrm{Ca}}$ by $24 \mathrm{~h}$ suggests that $\alpha_{1}$ subunit mRNA levels reflect subsequent changes in the amount of functional calcium channels in cardiomyocytes.

Alterations in abundance of ion channels in cardiac muscle may occur in response to physiological as well as pathophysiological stimuli. During cardiac development, it has been long appreciated that there are important alterations in the shape of the action potential consistent with alterations in number or subtype of ion channels (31-33). We have reported previously that in the developing chick heart, approximately at the time of ingrowth of sympathetic nerves, there is a marked increase in abundance of DHP receptors (34). In an in vitro model of sympathetic innervation, we have also shown that calcium channel abundance is regulated (9). In animal models of heart failure and in human heart failure, conditions where sympathetic tone is high and circulating norepinephrine concentrations are markedly elevated, DHP message levels and receptor binding sites have been reported to be decreased (3), although that has not been a uniform finding (35).

The present study offers initial insights into the molecular mechanisms by which expression of an ion channel in heart may be regulated. Our observations on mechanisms of regulation of the DHP receptor message and binding site bear striking similarity to the observations of Morris et al. (36) on cross-regulation of the $\alpha_{1}$-adrenergic receptor by $\beta$-adrenergic agonists. We observed that when the protein kinase A signaling pathway was activated by receptor- or non-receptor-mediated signals, there was a rapid increase in message for the DHP receptor followed by a decline below control levels. Our observations are qualitatively and quantitatively similar to the observation of Morris et al. (36) that $\beta$-adrenergic receptordependent mechanisms increase and then produce a late decrease in message levels for the $\alpha_{1}$-adrenergic receptor.
Moreover, $\alpha$-adrenergic receptor stimulation decreases $\alpha_{1}$ receptor binding sites.

In our experimental system, increase in DHP receptor message was followed by increased DHP receptor binding sites and an increase in whole-cell $\mathrm{I}_{\mathrm{Ca}}$, which most likely represents an increase in the number of functional calcium channels in the sarcolemma. Because the L-type calcium channel is a heteromultimeric protein and other subunits of the channel are required for normal function $(4,5)$, one inference that might be drawn is that either there are "spare" $\alpha_{2}$ and $\beta$ subunits in the cytosol ready to be assembled with new $\alpha_{1}$ subunits, or alternatively, there is coordinate regulation of expression of multiple subunits of the calcium channel. We can offer no definitive proof for either of these possibilities with our present data. The whole-cell current recording data, lack of change of activation and inactivation kinetics, as well as the changes in message level and change in DHP binding sites, are all entirely consistent with the postulate that $\beta$-adrenergic agonist exposure leads to more functional channels in the sarcolemma. However, without single-channel recordings, we cannot absolutely exclude the alternative that although there is an increase in message and protein, the increase in $\mathrm{I}_{\mathrm{Ca}}$ is due to altered single-channel properties and not due to a greater number of functional channels.

There are limitations to this study. The experimental system is neonatal cells, and therefore regulatory mechanisms may not be identical to those of adult ventricular myocytes. We believe we were able to isolate catecholamine effects in this in vitro system because the cells were maintained in serum-free medium devoid of growth factors (including the catecholamines present in serum), and in control cells, DHP receptor message levels were constant throughout the course of the experiment. We did not follow the experiments over a sufficiently long temporal course to determine whether subsequent to a decline in DHP receptor message levels, there was an eventual decline in DHP receptor protein. We were not confident that the neonatal myocyte culture system would retain sufficient phenotypic stability over an adequately long time course for definitive experiments. Finally, the species studied was rat. Although $\beta$-adrenergic signaling processes observed in rat have usually been generalizable to other species, the $\alpha$-adrenergic receptor protein kinase $\mathrm{C}$-dependent pathway in rat may differ at least quantitatively from other species. Therefore, one must extrapolate our findings to other species with caution.

In conclusion, our experiments on catecholamine-induced regulation of the $\alpha_{1}$ subunit of the L-type calcium channel in cultured neonatal rat ventricular myocytes offer novel insights into mechanisms by which ion channels may be regulated. In this system, catecholamines regulate expression of calcium channel $\alpha_{1}$ subunit mRNA, ligand binding sites, and whole-cell $\mathrm{I}_{\mathrm{Ca}}$ through both $\beta$-adrenergic and $\alpha$-adrenergic pathways.

\section{Acknowledgments}

We appreciate the excellent assistance of Ms. Linda Jimenez in the preparation of this manuscript.

This study was supported in part by grants from the National Institutes of Health (RO1-HL35781 to J.D. Marsh, RO1-HL42539 to W. Colucci, and R01-NS29814 to A.R. Marks who is a Bristol-Meyers Squibb Established Investigator of the American Heart Association), a Fogarty International Fellowship (F05 TW04685 to T. Maki), a 
grant from Sandoz Pharmaceuticals (to J.D. Marsh), and grants from Ella and Georg Ehrnrooth Foundation (Finland) and Paulo Foundation (Finland) (to T. Maki).

\section{References}

1. Marsh, J.D. 1989. Coregulation of calcium channels and beta-adrenergic receptors in cultured chick embryo ventricular cells. J. Clin. Invest. 84:817-823.

2. Ferrante, J., and D.J. Triggle. 1990. Drug- and disease-induced regulation of voltage dependent calcium channels. Pharmacol. Rev. 42:29-44.

3. Takahashi, T., P.D. Allen, R.V. Lacro, A.R. Marks, A.R. Denniss, F.J. Schoen, W. Grossman, J.D. Marsh, and S. Izumo. 1992. Expression of dihydropyridine receptor (Ca-channel) and calsequestrin genes in the myocardium of patients with end-stage heart failure. J. Clin. Invest. 90:927-935.

4. Singer, D., M. Biel, I. Lotan, V. Flockerzi, F. Hofmann, and N. Dascal. 1991. The roles of the subunits in the function of the calcium channel. Science (Wash. DC). 253:1553-1557.

5. Wei, X.Y., E. Perez-Reyes, A.E. Lacerda, G. Schuster, A.M. Brown, and L. Birnbaumer. 1991. Heterologous regulation of the cardiac $\mathrm{Ca}^{2+}$ channel $\alpha_{1}$ subunit by skeletal muscle $\beta$ and $\gamma$ subunits. Implications for structure of the cardiac L-type Ca ${ }^{2+}$ channel. J. Biol. Chem. 266:21943-21947.

6. Perez-Reyes, E., H.S. Kim, A.E. Lacerda, W. Horne, X.Y. Wei, D. Rampe, K.P. Campbell, A.M. Brown, and L. Birnbaumer. 1989. Induction of calcium currents by the expression of $\alpha_{1}$ subunits of the dihydropyridine receptor from skeletal muscle. Nature (Lond.). 340:233-236.

7. Mikami, A., K. Imoto, T. Tanabe, T. Niidome, Y. Mori, S. Takeshima, S. Narumiya, and S. Numa. 1989. Primary structure and functional expression of the cardiac dihydropyridine-sensitive calcium channel. Nature (Lond.). 340: $230-233$

8. Diebold, R.J., W.J. Koch, P.T. Ellinor, J.-J. Wang, M. Muthuchamy, D.F. Wieczorek, and A. Schwartz. 1992. Mutually exclusive exon splicing of the cardiac calcium channel $\alpha_{1}$ subunit gene generates developmentally regulated isoforms in the rat heart. Proc. Natl. Acad. Sci. USA. 89:1497-1501.

9. Ogawa, S., J.V. Barnett, L. Sen, J.B. Galper, T.W. Smith, and J.D. Marsh. 1992. Direct contact between sympathetic neurons and rat cardiac myocytes in vitro increases expression of functional calcium channels. J. Clin. Invest. 89: $1085-1093$.

10. Keung, E.C., and J.S. Karliner. 1990. Complex regulation of calcium current in cardiac cells. J. Clin. Invest. 85:950-954.

11. Gengo, P.J., N. Bowling, V.L. Wyss, and J.S. Hayes. 1988. Effects of prolonged phenylephrine infusion on cardiac adrenoceptors and calcium channels. J. Pharmacol. Exp. Ther. 244:100-105.

12. Cohn, J.N., T.B. Levine, M.T. Olivari, V. Garberg, D. Lura, G.S. Francis, A. Simon, and T. Rector. 1984. Plasma norepinephrine as a guide to prognosis in patients with chronic congestive heart failure. N. Engl. J. Med. 311:819823.

13. Mercardier, J.J., A.M. Lompre, P. Duc, K.R. Boheler, J.B. Fragsne, C. Wisenewsky, P.D. Allen, M. Komajda, and K. Schwartz. 1990. Altered sarcoplasmic reticulum $\mathrm{Ca}^{2+}$-ATPase gene expression in the human ventricle during endstage heart failure. J. Clin. Invest. 85:305-309.

14. Libby, P. 1984. Long-term culture of contractile mammalian heart cells in a defined serum-free medium that limits non-muscle cell proliferation. $J$. Mol. Cell. Cardiol. 16:803-811.

15. Mohamed, S.N., R. Holmes, and C.R. Hartzell. 1983. A serum-free, chemically defined medium for function and growth of primary neonatal rat heart cell cultures. In Vitro (Rockville). 19:471-478.

16. Ellingsen, Ø., A.J. Davidoff, S.K. Prasad, H.J. Berger, J.P. Springhorn,
J.D. Marsh, R.A. Kelly, and T.W. Smith. 1993. Adult rat ventricular myocytes cultured in defined medium: phenotype and electromechanical function. Am. $J$. Physiol. 265:H747-H754.

17. Gillo, B., Y.S. Ma, and A.R. Marks. 1993. Calcium influx in induced differentiation in murine erythroleukemia cells. Blood. 81:783-792.

18. Brillantes, A.M., S. Bezprozvannaya, and A.R. Marks. 1994. Developmental and tissue-specific regulation of rabbit skeletal and cardiac muscle calcium channels involved in excitation-contraction coupling. Circ. Res. 75:503510.

19. Ma, Y., E. Kobrinsky, and A.R. Marks. 1995. Cloning and expression of a novel truncated calcium channel from non-excitable cells. J. Biol. Chem. 270: 483-493.

20. Chomczynski, P., and N. Sacchi. 1987. Single-step method of RNA isolation by acid guanidium thiocyanate-phenol-chloroform extraction. Anal. Biochem. 162:156-159.

21. Cotecchia, S., D.A. Schwinn, R.R. Randall, R.L. Lefkowitz, M.G. Caron, and B.K. Kobilka. 1988. Molecular cloning and expression of the cDNA for the hamster $\alpha_{1}$-adrenergic receptor. Proc. Natl. Acad. Sci. USA. 85:71597163.

22. Lee, R.T., K.D. Bloch, J.M. Pfeffer, M.A. Pfeffer, E.J. Neer, and C.E. Seidman. 1988. Atrial natriuretic factor gene expression in ventricles of rats with spontaneous biventricular hypertrophy. J. Clin. Invest. 81:431-434.

23. Marsh, J.D., and T.W. Smith. 1985. Receptors for beta-adrenergic agonists in cultured chick ventricular cells: relationship between agonist binding and physiologic effect. Mol. Pharmacol. 27:10-18.

24. Katzka, D.A., R. Cox, A.J. Davidoff, and M. Morad. 1992. Permeation of divalent cations through the $\mathrm{Ca}^{2+}$ channel of rabbit portal vein myocytes. Am. J. Physiol. 262:H326-H330.

25. Balke, C.W., and W.G. Wier. 1992. Modulation of L-type calcium channels by sodium ion. Proc. Natl. Acad. Sci. USA. 89:4417-4421.

26. Bean, B. 1992. Whole-cell recording of calcium channel currents. Methods Enzymol. 207:181-193.

27. Aiba, S., and T.L. Creazzo. 1993. Comparison of the number of dihydropyridine receptors with the number of functional L-type calcium channels in embryonic heart. Circ. Res. 72:396-402.

28. Collins, S., M.G. Caron, and R.J. Lefkowitz. 1991. Regulation of adrenergic receptor responsiveness through modulation of receptor gene expression. Annu. Rev. Physiol. 3:497-508.

29. Marsh, J.D., D. Lachance, and D. Kim. 1985. Mechanisms of betaadrenergic receptor regulation in cultured chick heart cells: role of cytoskeleton function and protein synthesis. Circ. Res. 57:171-181.

30. Izzo, N.J., Jr., C.F. Seidman, S. Collins, and W.S. Colucci. 1990. Alpha-1 adrenergic receptor mRNA level is regulated by norepinephrine in rabbit aortic smooth muscle cells. Proc. Natl. Acad. Sci. USA. 87:6268-6271.

31. Sperelakis, N., and K. Shigenobu. 1972. Changes in membrane properties of chick embryonic hearts during development. J. Gen. Physiol. 60:430-453.

32. Langer, G.A., A.J. Brady, S.T. Tan, and S.D. Serena. 1975. Correlation of the glycoside response, the force staircase, and the action potential configuration in the neonatal rat heart. Circ. Res. 36:744-752.

33. Toshe, N., H. Masuda, and N. Sperelakis. 1992. Novel isoforms of $\mathrm{Ca}^{2+}$ channels in rat fetal cardiomyocytes. J. Physiol. (Lond.). 451:295-306.

34. Marsh, J.D., and P.D. Allen. 1989. Developmental regulation of cardiac calcium channels and contractile sensitivity to [Ca $]_{0}$. Am. J. Physiol. 256:H179H185.

35. Rasmussen, R.P., W. Minobe, and M.R. Bristow. 1990. Calcium antagonist binding sites in failing and on failing human ventricular myocardium. Biochem. Pharmacol. 39:691-696.

36. Morris, G.M., J.R. Hadcock, and C.C. Malbon. 1991. Cross-regulation between G-protein-coupled receptors. J. Biol. Chem. 266:2233-2238. 